\title{
Psikoterapistlerin çevrimiçi yürütülen psikoterapilere yönelik algılarına ilişkin bir tematik analiz çalışması
}

\author{
Burcu Korkmaz ${ }^{1}$, Gamze Şen ${ }^{2}$
}

\author{
Anahtar kelimeler \\ çevrimiçi psikoterapi, \\ internet, terapist alg1lar1, \\ nitel yöntem, tematik \\ analiz
}

\section{Key words}

online psychotherapy, Internet, therapist perceptions, qualitative method, thematic analysis

\begin{abstract}
Öz
Teknolojinin ve internetin kullanım alanlarının gelişmesi ve artması, psikoterapi uygulamalarının ve ruh sağlığına müdahalelerin yüz yüze yürütülen geleneksel bağlamlarının dışında yeni ve kullanımı giderek yaygınlaşan bir alanın gelişmesine yol açmıştır. Bu çalışmanın amacı da, halen ülkemizde kullanım sıklığı ve alanyazın arka planı sınırlı kalan çevrimiçi yürütülen psikoterapi süreçlerine ilişkin psikoterapistlerin algılarının ve düşüncelerinin değerlendirilmesidir. Araştırmaya, Türkiye'nin farklı illerinde çalışan 39'u kadın (\%86.7) ve 6'sı erkek (\%13.3) olmak üzere toplam 45 psikoterapist katılmıştır. Elde edilen veriler, bir nitel analiz yöntemi olan 'tümevarımsal tematik analiz (inductive thematic analysis) prosedürü kullanılarak göre analiz edilmiştir. Elde edilen bulgulara göre, Türkiye'deki psikoterapistlerin çevrimiçi psikoterapilere ilişkin algıları sekiz farklı tema altında toplanmıştır. Bu temalar; 1) kaygı uyandıran bir bağlam olarak çevrimiçi psikoterapi, 2) uygun olmayan bir bağlam olarak çevrimiçi psikoterapi, 3) yedek/koşullu bir bağlam olarak çevrimiçi psikoterapi, 4) özel eğitim ve bilgi gerektiren bir bağlam olarak çevrimiçi psikoterapi, 5) suistimale açık bir bağlam olarak çevrimiçi psikoterapi, 6) aksiliklere açık bir bağlam olarak çevrimiçi psikoterapi, 7) ulaşılabilirliği yüksek bir bağlam olarak çevrimiçi psikoterapi ve 8) yüz yüze terapiden farklı olmayan bir bağlam olarak çevrimiçi psikoterapidir. Elde edilen bu bulgular, psikoterapistlerin çevrimiçi terapilerin kullanıma uygun ve kolaylaştırıcı yönlerinin farkında olmalarına rağmen, halen olumsuz özelliklerine yoğun şekilde atıfta bulunduklarına işaret etmektedir. Araştırma sonuçları, hem uygulama hem de araştırma alanlarında psikoterapinin önümüzdeki süreçte nasıl şekillenebileceğine yönelik önemli noktalara dikkat çekmektedir.
\end{abstract}

Abstract

A thematic analysis study on psychotherapists' perceptions of online psychotherapies The development and growth of technology and internet use has led to the development of a new and increasingly widespread field in psychotherapy practices and mental health interventions other than face-to-face traditional contexts. The purpose of this study is to assess the perceptions and beliefs of psychotherapists regarding online psychotherapy processes, which still have a limited usage and literature background in Turkey. The participants of the present study consisted of 45 psychotherapists working in various provinces of Turkey, of which $39(86.7 \%)$ were female and $6(13.3 \%)$ were male. The obtained data was analyzed using inductive thematic analysis procedure, a qualitative analysis method. According to the findings, perceptions of online psychotherapies of the psychotherapists in our country are grouped under eight different themes. These included 1) online psychotherapy as a worrisome context, 2) online psychotherapy as an inappropriate context, 3) online psychotherapy as a reserve/conditional context, 4) online psychotherapy as a context requiring specialized education and information, 5) online psychotherapy as a context prone to misconduct, 6) online psychotherapy as context prone to problems; 7) online psychotherapy as a context with high accessibility; and 8) online psychotherapy as context not different from face-to-face psychotherapy. The findings indicate that, although psychotherapists are aware of the appropriate and facilitating aspects of online therapies, they still refer intensely to their negative features. These findings provide insights on how psychotherapies, in both practice and research, will change in the future.

Korkmaz, B. ve Şen, G. (2018). Psikoterapistlerin çevrimiçi yürütülen psikoterapilere yönelik algılarına ilişkin bir tematik analiz çalışması. Klinik Psikoloji Dergisi, 2(3), 140-152.

\footnotetext{
Burcu Korkmaz·psy.burcukorkmaz@gmail.com

${ }^{1}$ Arş. Gör., Uludağ Üniversitesi, Fen Edebiyat Fakültesi, Sosyal

Bölümler Binası, Nilüfer/Bursa, 16059.

${ }^{2}$ Arş. Gör., Necmettin Erbakan Üniversitesi, Psikoloji Bölümü,

Selçuklu/Konya, 42060
}

Geliş tarihi: 08.07.2018

Kabul tarihi: 29.09.2018 
Teknolojinin hızla gelişmesinin ve bilgisayar ile internet kullanımının 90'lı yılların ortalarından itibaren büyük oranda artmasının etkisiyle, sağlık çalışanlarının hizmet verme yolları da benzer hızla değişmektedir (Wolf, 2011). İnternetin evlerde, iş yerlerinde, okullarda ve devlet kurumlarında kullanılmaya başlanması ile birlikte hem çalışanlar hem de hizmet alanlar açısından vazgeçilmez firsatlar ve değişiklikler sağlanmıştır (Barak, Klein ve Proudfoot, 2009). Bu değişimden etkilenen alanlardan biri de psikoterapi sürecinin yürütüleceği bağlamdır. Özellikle terapistlerin telefon, elektronik posta (e-posta), video görüşmesi gibi yollarla da terapi sürecini yürütmesi, bir yandan uygulama kolaylığg ve avantajları sebebiyle desteklenirken, diğer yandan kötüye kullanılabileceği kaygısıyla araştırmacılar ve ruh sağlığı çalışanları tarafından eleştirilmektedir. Örnek olarak, geleneksel psikoterapi yaklaş1$\mathrm{m} 1$ ve öğretileri, pek çok nedenle terapist ve danışanın aynı odada bulunması gerektiğini ve psikoterapistlere verilen eğitimlerde yüz yüze iletişimin 'ideal' olduğunu vurgulamaktadır (Day ve Schneider, 2002). Bu zitlik son yillarda psikoterapistler arasında sıklıkla tartışılan konulardan biri haline gelmiştir. Özellikle teknoloji ve psikoterapi uygulamaları anlamında ortaya çıkan kavramların tanımlanması, etik konular, etkililik ve karşılaşılabilecek potansiyel zorluklar tartışmaların temel başlıklarıdır (Rochlen, Zack ve Speyer, 2004). Tartışmaların odağında yer alan başlıklardan ilki, henüz netleşememiş ve işevuruk tanımları yaygınlaşmamış olan kavramlar üzerinedir. İnternet üzerinden gerçekleştirilen psikoterapötik müdahaleler için pek çok anahtar kelime kullanılmakta (internet-temelli terapi, e-terapi, sanal-terapi, e-müdahale, bilgisayar aracılığı ile müdahale, çevrimiçi terapi vs.), ancak aralarındaki farklılıklar net olarak anlaşılamamaktadır. Barak ve arkadaşlarına (2009) göre, psikoterapi uygulamalarında internet kullanımının genişlemesine rağmen bu kullanım açıklıktan ve tutarl1liktan uzaktır. Bilim insanları ve profesyoneller bu alandaki çalışmalarını birbirinden bağımsız ve karş1lıklı iletişim kurmadan; kabul edilmiş standartlar ve benimsenmiş terminoloji ve metodoloji üzerinde uzlaşı sağlayamadan sürdürmektedir. Rochlen ve arkadaşları (2004), çevrimiçi psikoterapileri 'terapistler ile danışanları arasındaki etkileşimin internet yoluyla sağlandığı bir tür profesyonel terapötik müdahale' olarak tanımlamaktadırlar (s. 270). Dolayısıyla tele-sağlık, tele-psikiyatri, mektupla ya da e-posta ile müdahale gibi yüz yüze ve senkronize şekilde gerçekleştirilmeyen diğer hizmetlerden, danışan ve terapist arasındaki 'etkileşim'in senkronize varlığ 1 ile ayrılmaktadır. Bu çalışma kapsamında da Rochlen ve arkadaşlarının (2004) tanımlamış olduğu 'çevrimiçi terapiler' ele alınmıştır.
Psikoterapinin internet aracılığıyla (çevrimiçi) yürütülmesi konusundaki tartışmaların diğer bir başlığını da etik konular oluşturmaktadır. Psikoterapi ve teknoloji kullanımı arasındaki ilişkiden özellikle gizlilik ilkesinin zarar görüp görmeyeceğine ilişkin endişeler dikkatleri çekmektedir. Örnek olarak; Young'a (2005) göre danışanlar seansların gizliliğinin sağlanması konusunda kaygı yaşamaktadırlar; bu sebeple ruh sağlığı uzmanları her ne kadar gizlilik ilkelerini açıklamış ve danışanları ile tartışmış olsalar da, danışanların gizliliğin tamamen sağlanabildiğine ilişkin halen kaygı duyabileceklerini göz önünde bulundurmaları gerekmektedir. Tartışmaların bir diğer önemli odak noktası ise terapötik ittifak gibi önemli bir değişkenin bu sanal bağlamlardan nasıl etkilendiğidir. Bordin (1979) terapötik ittifakı; danışan ve terapist arasındaki duygusal bağın varlığı, terapi ödevleri/görevleri konusunda terapist ve danışanın katılımının kalitesi ve terapi hedefleri hakkında terapist ve danışan arasındaki uyum düzeyi olarak tanımlamıştır. Terapötik ittifak, psikoterapi araştırmalarının ele aldığ 1 en önemli değişkenlerden biridir ve özellikle terapi sonuçlarının en önemli yordayıcısı olarak düşünülmektedir (Hovarth, Del Re, Flückiger ve Symonds, 2011). Ancak geleneksel (yüz yüze) terapi bağlamlarının dışına çıkıldığında ve görüşmelerin sanal ortamda sürdürülmesi koşulunda pek çok araştırmac1 ve psikoterapist, terapötik ittifakın olumsuz yönde etkilenebileceğinden endişe duymuşlardır. Örneğin, Rees ve Stone (2005) yürütmüş oldukları çalışmada terapistlerin video görüşmesi aracillğ terapi sürecini yürütmesinin terapötik ittifakın gelişimi üzerinde bozucu etkisi olabileceğini düşündükleri; danışanların bu yolla gerçekleşen terapi seanslarında terapistin sıcaklığını, empatisini, hassasiyetini ve anlayışını algılayabilmesi ile ilgili endişe duydukları sonucuna ulaşmışlardır. Ayrıca araştırmacilar, terapistlerin terapi sürecinde teknolojiyi kullanma konusundaki olumsuz inançlarının farkında olmaları gerektiğini, bu farkındalığın sağlıklı tartışmaların yürütülmesi ve uygunluğun arttırılmas1 noktasında olumlu etkisi olabileceğini vurgulamaktadırlar. $\mathrm{Bu}$ yol, terapistlerin çevrimiçi terapi bağlamlarını kendi uygulamalarına nasıl dâhil edebileceklerine karar vermelerinde yardımcı olacaktır (Taylor ve Luce, 2003). Cook ve Doyle'e (2002) göre ise klinik endişelerin en temeli güçlü bir terapötik ilişkinin kurulup kurulamayacağına dayanmaktadır. Çünkü onlara göre sözel olmayan ipuçlarının olmaması, terapötik ilişkinin kurulmasında bozucu etkiye sahip olacaktır. Ancak diğer yandan, internet üzerinden yürütülen görüşmelerde, anonimliğin etkisi ile danışanların kendilerine dair daha çok kişisel bilgiler paylaşabileceğini, kendilerini daha kolay açabileceklerini ve terapist tarafindan reddedilme korkusunun daha hizlıca üstesinden 
gelinebileceğini bildiren görüşler de mevcuttur (McKenna, 1998). Bu görüşlerin yanında pek çok çalışma ise, çevrimiçi terapilerde de en az yüz yüze terapi kadar terapötik ittifak kurulabileceğini göstermiştir (Andersson ve ark., 2012; Antony, 2000; Cook ve Doyle, 2002; Day, 1999; Day ve Schineder, 2002; Hanley, 2004; Kiropoulos ve ark., 2008; Knaevelsrud ve Maercker, 2006, 2007; Preschl, Maercker ve Wagner, 2011; Reynolds, Stiles ve Grohol, 2006; Wagner, Brand, Schulz ve Knaevelsrud, 2012). Bu noktada danışan özelliklerinin yanı sıra terapistle ilişkili faktörlerin çevrimiçi terapi sürecini etkileyip etkilemediği sorusu akla gelse de, Almlöv ve arkadaşlarının (2009) yürütmüş oldukları çalışmanın bulguları yapılandırılmış terapi seanslarının çevrimiçi terapide de terapiste ilişkin faktörlerden etkilenmediğine vurgu yapmaktadır.

Tüm bu kaygılar, eleştiriler ve görüşlere rağmen kâr-zarar dengesindeki artıları sebebiyle internet temelli ve çevrimiçi uygulamalara adapte edilebilecek psikoterapi müdahalelerinin geliştirilmesi, kullanılması, etkililiğinin değerlendirilmesi ve yüz yüze terapilerle karşılaştırılması eksenindeki pek çok çalışma alanyazında yer almaktadır. Çünkü bir dönem teknolojinin henüz sinırl kalması sebebiyle (görüntü kalitesinin yetersizliği gibi) birtakım kaygılar bildirilmiş olsa da (Castelnuova, Gaggioli, Mantovani ve Riva, 2003); teknolojinin olağanüstü hızla gelişmesi, neredeyse gerçekliğe yakın hız ve kaliteye ulaşması, çevrimiçi yürütülen ruh sağlığ hizmetinin halihazırda gündemde kalmasına ve gelecekte oldukça geliştirilebileceği (Norcross, Hedges ve Prochaska, 2002) düşüncesine yol açmaktadır. Bu düşünceyi test etmek amaciyla Day ve Schneider (2002), sesli, görüntülü ve yüz yüze müdahale bağlamları arasında anlamlı bir farkın olmadığı sonucuna ulaşmışlardır. Rees ve Stone'a (2005) göre, uzak mesafeden teknoloji aracılığıyla psikoterapi hizmeti verilebiliyor olması yüz yüze terapiye katılımda zorluk yaşayabilecek pek çok insanın (kırsal alanlarda yaşayan bireyler, tutuklu bireyler, askeri görevleri olan bireyler, dezavantajlı gruplar ve engelli bireyler gibi) katılımını sağlayabilmektedir. Ayrıca Haberstroth ve arkadaşlarına (2007) göre, çevrimiçi müdahaleler teknoloji kullanımı konusunda deneyimli ve çevrimiçi iletişim kanallarını gündelik hayatlarında kullanan bireylerde daha fazla yardımc bir yol olabilmektedir. Dolayısıyla, psikoterapide bilgisayar teknolojilerinin kullanılmas1 ile ilgili her ne kadar büyük oranda önyarg1 ve ruh sağlığı çalışanlarının bu yolla yürütülen terapilerde 'yapay' ilişkiler kurulacağına dair endişeleri söz konusu olsa da, günümüzde pek çok insanın bilgisayarlarla büyümesi ve her profesyonel ofiste bilgisayarların bulunması sebebiyle, bazı araştırmac1lar psikoterapinin çevrimiçi şekilde yürütülmesini kullanışlı bulmaktadırlar (Hartwich ve Brandecker,
1997); bu görüşü desteklemeye yönelik pek çok çalışma alanyazında yer almaktadır. Travma sonrası stres bozukluğu (TSSB) (Klein ve ark., 2010; Knaevelsrud ve Maercker, 2007, 2009; Lange ve ark., 2003; Wagner, Knaevelsrud ve Maercker, 2006); depresyon (Andersson, Cuijpers, Carlbring, Riper ve Hedman, 2014; Beattie, Shaw, Kaur ve Kessler, 2009; Johansson ve Andersson 2012; Wagner, Horn ve Maercker, 2014; Warmerdam, Straten, Jongsma, Twisk ve Cuijpers, 2010) ve kayg1 bozuklukları (Kenardy ve ark., 2003; Spence ve ark., 2008) gibi bozuklukların tedavisinde çevrimiçi psikoterapi yaklaşımının kullanıldığı ve yüz yüze terapilerle karşılaştırıldığı çalışmalardan elde edilen bulgular oldukça dikkat çekicidir. Tüm çalışmaların ortak noktası yüz yüze terapinin 'olmazsa olmaz' özellikte olmadığı; çevrimiçi yürütülen psikoterapilerin etkili, bütünleyici ve daha kârlı bir alternatif sunduğu yönündedir. Bunlar gibi pek çok araştırma, psikoterapi araştırmalarına yeni bir bakış açısı kazandırmanın önünü açmıştır.

Müdahale çalışmalarının yanı sıra, Mora, Nevid ve Chaplin'e (2008) göre bu alanın geleceğini terapistlerin çevrimiçi terapilere yönelik algıları da etkileyecektir. Bu sebeple araştırmacılar, psikoterapistlerin çevrimiçi terapilere ilişkin tutumlarını incelemişler; elde ettikleri sonuçlara göre örneklemlerinde yer alan psikologlar; Wangberg, Gammon ve Spitznogle'ın (2007) çalışmasının aksine, çevrimiçi müdahaleleri yüz yüze terapiye ek ya da alternatif bir yol olarak ele almada bazı kaygılar (sözel olmayan davranışları gözlemleyememe, terapötik ittifakın kurulmasında güçlükler yaşama, yasal rehberlerin olmaması gibi) yaşamaktadırlar. Terapistler, çevrimiçi psikoterapiyi yüz yüze terapinin alternatif bir yolu olarak ele almaktansa, yüz yüze terapiye ek bir müdahale yolu olarak değerlendirme eğilimindedirler.

Psikoterapi sürecinin geleceğine ilişkin uzmanların öngörülerini inceleyen araştırmalar gerek ülkemizde gerekse de dünya genelinde giderek yaygınlaşmaktadır. Ülkemizde Yorulmaz ve arkadaşları (2018) tarafindan yürütülen çalışmada gelecekte artışı beklenen terapötik müdahaleler arasında internet tabanlı programlar, akıllı telefon uygulamaları bulunmaktadır. Psikoterapötik müdahalenin türüne göre, sertifika/yüksek lisans derecesine sahip aile danışmanlarının ve internet tabanlı tedavi programlarının daha yaygın hale gelmesi beklenirken, daha kısa tedavi formatlarının ve krize müdahale yaklaşımlarının tercih edileceği düşünülmektedir. Norcross ve arkadaşları (2002) çalışmalarında psikoterapinin on y1l sonraki sürecine ilişkin uzmanların öngürüsünü araştırmış ve uzmanlar beş alanda psikoterapi sürecinin en hızlı şekilde gelişeceğini ön görmüşlerdir. Bu beş alan çevrimiçi psikoterapiler, akıllı telefon uygulamalar1, kendine yardım 
kitaplarının ötesindeki kaynaklar, sanal gerçeklik uygulamaları ve sosyal ağ müdahaleleri olarak ifade edilmiştir. Tüm dünyada giderek yaygınlaşan ve belirli bir alanyazın arka planına sahip bu alanın, psikoterapistlerin çevrimiçi yürütülen psikoterapilere yönelik bu günkü algılarına ilișkin henüz ülkemizdeki araştırmacılar tarafından yeteri kadar çalışılmamış olması dikkat çekicidir. Bu sebeple başlangıç noktası olarak, terapistlerin bu alanla ilgili algılarının, düşüncelerinin ve değerlendirmelerinin anlaşılmasının önemli olduğu düşünülmektedir.

Çevrimiçi terapilerin faydaları ve zorlukları hakkında pek çok tartışma alanyazında yer alsa da, çok az çalışma bu fayda ve zorlukların uygulayıcılar ve kullanıcılar tarafindan gerçekten nasıl alg1landığını incelemiştir (Rochlen ve ark., 2004). Andersson'a (2009) göre başlangıç noktası olarak, terapistlerin psikoterapi bağlamı olarak internet kullanımına ilişkin algıları incelemek oldukça önemlidir. Psikologların psikoterapide internetin kullanımına ilişkin algılarını değerlendiren Wangberg ve arkadaşları (2007) ise, çoğu psikoloğun nötr; küçük bir grup psikoloğun ise olumsuz algıları olduğu sonucuna ulaşmışlardır. Elde ettikleri diğer bir önemli bulgu da Mora ve arkadaşlarının (2008) çalışması ile de tutarlı olarak, bilişsel psikoterapi yönelimi olan terapistlerin, psikodinamik yönelimli olanlara göre daha olumlu tutumlara sahip olduklarını göstermeleridir. Ülkemizde ise psikoterapide internetin kullanımına ilişkin çalışmalar oldukça kısıtlı kalmakla birlikte, terapistlerin algılarını inceleyen herhangi bir çalışma alanyazında yer almamaktadır. Terapistlerin çevrimiçi terapilere yönelik algılarının, bu terapi bağlamının kullanımının sıkl1ğını, psikoterapi hizmetinin veriliş yollarını ve yönlendirmeleri, alanyazındaki psikoterapi araştırmalarının odak noktasını, belirli etik ve terapötik çerçeve düzenlemelerini etkileyebileceği düşünülmektedir. Bu sebeple psikoterapistlerin algılarını değerlendirmek ve bu algılar ile olası kaygılara ilişkin belirli bir çerçeve geliştirebilmek oldukça önemlidir. Çevrimiçi terapilerin kimler için uygun olduğu veya uygun olmadığına dair pek çok görüş olsa da (Stofle, 2001; Suler ve ark., 2001) bu doğrultuda bu çalışmanın amacı nitel yöntemin derinlemesine bulgu sunabilme avantajı ile birlikte, Türkiye'de yaşayan ve çalışan psikoterapistlerin çevrimiçi terapilere ilişkin algılarını doğrudan psikoterapistlerden ögrrenebilmek, psikoterapistlerin çevrimiçi terapilere yönelik eylemsel öngörülerini belirleyebilmek, çevrimiçi psikoterapi bağlamını kullanan ve kullanmayan terapistlerin ifadelerindeki farklılaşmaları değerlendirebilmektir.

\section{YÖNTEM}

\section{Örneklem}

Araştırmamızda klinik psikoloji alanında yüksek lisans ve/veya doktora düzeyinde eğitimlerini sür- düren veya tamamlamış toplam 48 katılımcı yer almış, 3 katılımcı daha önce hiç psikoterapi uygulama deneyimi olmaması sebebiyle örneklemden çıkartılmıştır. Analizler, yaşları 24 ile 44 arasında değişen (Ort. $=26.07, S=2.31)$, 39'u kadın (\%86.66) ve 6'i erkek (\%13.33) olmak üzere toplam 45 terapist ile gerçekleştirilmiştir. Katılımcıların yaş ortalamaları kadınlar için $28.17(S=3.21)$ ve erkekler için $31.07(S=4,05)$ 'dir. Katılımcıların düzenli takip ettikleri danışan sayısı haftada 0 ile 30 arasinda (Ort. $=7,64, S=4.77)$; alan deneyimleri ise 0 ile 10 yil arasinda $($ Ort. $=4.00, S=2.27)$ değişmektedir. Katılımcıların 15'i (\%33.33) daha önce çevrimiçi psikoterapi süreci yürüttüğünü belirtirken, 30'ü (\%66.7) daha önce hiç çevrimiçi psikoterapi sürecini yürütmediğini ifade etmiştir. Kat1lımcılara ilişkin demografik bilgiler Tablo 1'de yer almaktadır.

\section{Veri Toplama Araçları}

Demografik Bilgi Formu Kat1lımc1lara demografik formda yaş, cinsiyet, yaşadıkları yer, eğitim durumu, çalıştığı kurum, haftalık düzenli takip ettiği danışan sayısı, uygulama alanındaki deneyim süresi, psikoterapi uygulamalarında benimsediği kuramsal yaklaşım, psikoterapi uygulamalarında hangi yaş grubu ile çalıştı̆̆ 1 gibi bilgileride içeren sorular yöneltilmiştir.

\section{Psikoterapistlerin Çevrimiçi Terapilere Yönelik} Algılarını Değerlendirme Formu Katılımcılara iletilen formda psikoterapistlerin çevrimiçi bağlamda yürütülen psikoterapi süreçlerine yönelik algılarını belirleyebilmek amaciyla katılımcı psikoterapistlere 6 adet açık uçlu soru yöneltilmiştir. $\mathrm{Bu}$ soruların geliştirilmesinde ve katılımcılara yöneltilmesinde hem ilgili alanyazından elde edilen bulgulardan ve görüşlerden yararlanılmış, hem de bu çalışmanın araştırmacılarının kendi uygulamalarından ve deneyimlerinden yola çıkılmıştır. Katılımcılara yöneltilen sorulara Tablo 2'den ulaşılabilir. Ayrıca psikoterapistlerin çevrimiçi psikoterapilere yönelik eylemsel öngörülerini değerlendirebilmek adına da iki farklı soru da yöneltilmiştir. Bu sorular, 1) Yetkinlik alanınıza girmeyen ve size başvuran bir danışanınızı bu konuda internet üzerinden yürütülen terapi yaptığını bildiğiniz bir meslektaşınıza yönlendirir misiniz? ve 2) İnternet üzerinden psikoterapi süreci yürütülen bir terapiye, kendiniz dan1şan olarak gitmeyi tercih eder miydiniz? şeklindedir.

\section{İşlem}

$\mathrm{Bu}$ araştırmanın yürütülebilmesi için Hacettepe Üniversitesi Etik Komisyonu'ndan onay alınmıştır. 
Tablo 1. Katılımcıların Birinci Aşamada Demografik Özelliklere Göre Dağılımı

\begin{tabular}{|c|c|c|c|}
\hline Katılımcının & & $\%$ & $\mathrm{~N}=45$ \\
\hline \multirow[t]{2}{*}{ Yaşadığı yer } & Büyükşehir & 93.33 & 42 \\
\hline & Şehir & 6.66 & 3 \\
\hline \multirow[t]{3}{*}{ Eğitim durumu } & Lisans & 4.44 & 2 \\
\hline & Yüksek lisans & 51.11 & 23 \\
\hline & Doktora & 44.44 & 20 \\
\hline \multirow[t]{2}{*}{ Meslek } & $\begin{array}{l}\text { Arş. Gör. Klinik } \\
\text { psikolog }\end{array}$ & 46.66 & 21 \\
\hline & Klinik psikolog & 53.33 & 24 \\
\hline \multirow[t]{4}{*}{ Kurum } & Çalışmıyor & 2.2 & 1 \\
\hline & Üniversite & 46.66 & 21 \\
\hline & Kamu kuruluşu & 20.8 & 10 \\
\hline & Özel sektör & 28.88 & 13 \\
\hline \multirow{7}{*}{ 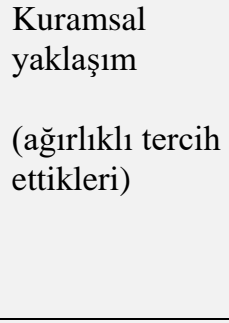 } & BDT & 15.55 & 7 \\
\hline & Şema & 6.66 & 3 \\
\hline & $\begin{array}{l}\text { Psikanalitik } \\
\text { psikoterapiler }\end{array}$ & 11.11 & 5 \\
\hline & Eklektik & 11.11 & 5 \\
\hline & BDT - Şema & 35.55 & 16 \\
\hline & BDT - Analitik & 11.11 & 5 \\
\hline & Şema - Analitik & 6.66 & 3 \\
\hline \multirow{5}{*}{$\begin{array}{l}\text { Çalıştığ1 yaş } \\
\text { grubu }\end{array}$} & Yetişkin & 57.77 & 26 \\
\hline & Çocuk-ergen & 4.44 & 2 \\
\hline & Çocuk-yetişkin & 11.11 & 5 \\
\hline & Ergen - yetişkin & 11.11 & 5 \\
\hline & Karma & 15.55 & 7 \\
\hline \multirow[t]{4}{*}{ Çalışma alanı } & Bireysel-yetişkin & 66.66 & 30 \\
\hline & Bireysel - oyun & 2.2 & 1 \\
\hline & Bireysel - grup & 13.33 & 6 \\
\hline & Bireysel - çift & 17.77 & 8 \\
\hline
\end{tabular}

Araştırmamız üç aşamayı içeren tek bir uygulamadan oluşmaktadır. Bu makalede ise ilk iki aşamadan elde edilen bulguların sunulması planlanmıştır. Birinci aşamada katılımcıların demografik özellikleri, yaş, cinsiyet ve eğitim durumu gibi bilgileri içeren bir demografik form uygulanmıştır. Çalışmanın ikinci aşamasında terapistlerin, bireysel psikoterapi sürecinin çevrimiçi yürütülmesine yönelik düşüncelerinin incelenmesi amaçlanmıştır. Bunu değerlendirmek için katılımcılara bazı açık uçlu sorular yöneltilmiştir. Hacettepe Üniversitesi, Orta Doğu Teknik Üniversitesi (ODTÜ), Ankara, İstanbul, Ege, Dokuz Eylül, Kocaeli, Okan, Haliç, Başkent, Maltepe ve Bahçeşehir Üniversiteleri'nin psikoloji bölümlerinde lisansütü eğitim alan ya da görev yapan kişiler ve de alanda çalışan terapistler araştırmanın katılımcı örneklemini oluşturmaktadır. Katılımcılara iki aşamayı da içeren tek bir uygulama formu mail adresleri yoluyla internet üzerinden iletilmiştir. Kat1limcilardan elde edilen veriler, Braun ve Clarke'ın (2006) tanımladığ1 'tümevarımsal tematik analiz' (inductive thematic analysis) prosedürüne göre analiz edilmiştir. Tematik analiz, oldukça sık olarak kullanılan, veri içerisinde yer alan temaların tanımlanmasını, analiz edilmesini ve raporlanmasını içeren bir yöntemdir; aynı zamanda veri setinin detaylı bir şekilde düzenlenmesini ve tanımlanmasını içerir
(Braun ve Clarke, 2006). Onlara göre tematik analiz, diğer nitel yöntemlerin temelidir ve en önemli avantajı kullanışlılığı ve esnekliğidir; yani belirli bir teoriden ya da epistemolojiden bağımsızdır. Bu doğrultuda araştırmacılar tarafından tematik analizin araştırma sorusunun incelenmesinde en uygun yöntem olduğuna karar verilmiştir. Bu doğrultuda ilk olarak veri seti dikkatlice, pek çok kez bu çalışmanın yürütücüleri tarafından okunmuş ve ayrı ayrı kodlanmıştır. Ardından araştırmacılar bir araya gelerek, ilk adımdan elde ettikleri kodları yorumlayarak tartışmışlar ve birlikte bu kodları belirli potansiyel temaların altında sıralamışlardır. Son olarak veri seti sistematik olarak yeniden gözden geçirilmiş, fikir birliğine varılan her bir temanın isimlendirilmesi ve açık şekilde yeniden tanımlanması gerçekleştirilmiştir.

\section{BULGULAR}

Araştırmamız sonucunda elde edilen verilerin tümevarımsal tematik analiz yöntemiyle değerlendirilmesi sonucu ortaya çıkan temalar sırasıyla aşağıda açıklanmaktadır.

\section{Tema 1: 'Kaygı uyandıran' bir bağlam olarak çevrimiçi psikoterapi}

Araştırmada katılımcı olarak yer alan psikoterapistlerin, çevrimiçi şekilde yürütülen psikoterapi süreçlerine yönelik kaygı duydukları ve oldukça dikkatli olunması gereken bir süreç olarak değerlendirdikleri gözlenmiştir. Özellikle danışanla yüz yüze herhangi bir görüşme yapmadan, doğrudan çevrimiçi olarak başlanılan süreçlere ilişkin kaygıların ve endişelerin daha çok vurgulandığı dikkatleri çekmektedir. Bu kaygının temelinde ise gizliliğin yeterince sağlanamayabileceği, terapötik ilişkinin kurulamayabileceği, sürecin ve danışanın belirsizliği, çevrimiçi seansların yüz yüze görüşmeler kadar 'samimi' olamayabileceği gibi durumlar yer almaktadır. Katılımcılar bu duruma ilişkin kaygılarını şu şekilde belirtmektedirler:

Katılımcı 33: '...ancak terapi sırasında oluşabilecek acil durumlar, müdahalenin uygulanmast, terapötik ilişkinin kurulması, gizliliğin sağlanması gibi konularda online terapilerin risk taşıdı ̆̆ını düşünüyorum.'

Katılımcı 2: '...uzun sure yüz yüze takip ettiğim bir danışanı daha sonra şehir değişikliği nedeniyle çevrimiçi olarak Skype üzerinden görmeye devam ediyorum. Bu koşul için çok pratik ama hiç yüz yüze buluşmadığım bir vaka ile nasıl olacağı konusunda kaygılarım olurdu:)'

Katılımcı 41: 'Günümüzde pek çok şey online. Terapilerde de bu söz konusu olabilir ancak bu durumun çeşitli zorlukları mümkün olabilir. Öncelikle bilgisayar üzerinden yapılan görüşmenin kaydının 
danışan veya terapist tarafindan kayda alınması ve etik ihlallerin söz konusu olabilmesi. Ayrica kameraya siğan yüz ifadesini yakalarken beden tarafindan bizlere gelebilecek sinyalleri kaçırmamı söz konusu olabilir. Danışanin veya terapistin online terapi anındaki mevcut koşullarında ortama başkalarının giriş-çıııı̧ını kontrol edebilmeleri zor olabilir...'

Katılımcı 28: '...olumlu baklyorum. Sadece daha önce hiç deneyimlemediğim için acaba yapay $m \imath$ olur gibi korkularım var. Ama eminim o hissiyat da tecrübesizliğimle alakalı'

Katılımcı 45: 'Online olarak yapılan hiçbir şeyin gizli kalmadığını düşünen birisiyim. Kendim bu kadar güvenmezken danışana gizlilik sözünü nasıl veririm, neye güvenerek veririm bilemiyorum. Danışanın riski kabul etmesi bile yeterli olmaz santrim.'

\section{Tema 2: 'Uygun olmayan' bir bağlam olarak çevrimiçi psikoterapi}

Katılımcıların çevrimiçi yürütülen psikoterapileri uygun olmayan bir bağlam olarak değerlendirdikleri, verilerden elde edilen önemli temalardan biridir. Buna göre psikoterapistler, psikoterapinin yalnızca yüz yüze yönetilebileceğini, çevrimiçi müdahalelerin 'gerçek bir temas ya da gerçek bir ilişki' sağlamayacağını ve ruh sağlığına müdahalenin sanal ortamda gerçekleştirilmesi açısından olanak sağlamayacağını bildirmektedirler. Dolayısıyla bazı problematik durumları ele alamamanın yaratabileceği bir kaygıdan ya da yüz yüze terapinin gerçekleşemediği koşullarda alternatif bir yol aranabileceğinden ziyade, daha katı bir düşünce ile çevrimiçi psikoterapilerin 'uygun olmadı̆̆ı' vurgulanmaktadir:

Katılımcı 14: '...Ĕger bir psikoterapi süreci online başlayıp online bitecekse bunun bana uygun bir yöntem olmadığını açıkça söyleyebilirim. Bana yapaylık, uzaklık duyguları ketleyici bir ortam sunuyor. ...Klasik anlamda kullanilan psikoterapiye muadil bir seçenek olamaz.'

Katılımcı 44: 'Uygun bulmuyorum zaten istismara açı bir meslek maalesef yetkisi olmayan bazı kişiler terapist saniyor kendisini'

Katılımcı 6: 'Yaşantısal bazı tekniklerin (sandalye çalışması gibi) online ortamda pek mümkün olmayacağını düşünüyorum. Mümkün olmayacaktan kastım ise yüz yüze olduğundaki kadar etkililik göstermeyeceği...'

Katılımcı 25: 'Terapi ilkelerinin uygun biçimde uygulanmasını, farkındalık ve sağaltım kazanılması konusunda kisıtlllıklara yol açtığını düşünüyorum.'
Tablo 2. Çevrimiçi Yürütülen Psikoterapilere İlişkin Psikoterapistlerin Algılarını Değerlendirebilmek Amacıyla Katılımcı Psikoterapistlere Yöneltilen Açık Uçlu Sorular

- Bireysel psikoterapi sürecinin internet üzerinden yürütülmesi hakkındaki görüşleriniz nelerdir?

- Bireysel psikoterapi sürecinde internet üzerinden yürütülen psikoterapileri terapi tekniklerinin uygulanması açısından nasıl değerlendirirsiniz?

- Bireysel psikoterapi sürecinde internet üzerinden yürütülen psikoterapileri terapötik iş birliği (terapötik ittifak) açısından nasıl değerlendirirsiniz?

- Bireysel psikoterapi sürecinde internet üzerinden yürütülen psikoterapileri meslek etiği açısından nasıl değerlendirirsiniz?

- Bireysel psikoterapi sürecinde internet üzerinden yürütülen psikoterapilerin uygun olacağını ve uygun olmayacağını düşündüğünüz koşullar nelerdir?

- Bireysel psikoterapi sürecinde internet üzerinden yürütülen psikoterapilerin avantajları ve dezavantajları nelerdir?

\section{Tema 3: 'Yedek/Koşullu’ bir bağlam olarak çevrimiçi psikoterapi}

Araştırmaya katılan psikoterapistlerden elde edilen verilere göre belirlenen temalardan bir diğeri de çevrimiçi psikoterapilerin neredeyse bir 'yedek' psikoterapi bağlamı olarak görülmesi ve bu bağlamın 'yüz yüze terapinin gerçekleştirilemeyeceği koşullarda' kullanılabileceğidir. Buna göre psikoterapistler, önceliği geleneksel yüz yüze terapiye vermekte, çevrimiçi yürütülen psikoterapileri ise psikoterapiye erişimi olmayan danışanlar için yüz yüze terapi ile aynı etkide olmasa da yine de kullanılabilecek bir yol olarak görmektedirler. Ayrica psikoterapistler bu koşuldaki kullanımı da yüz yüze yürütülen seanslarda terapötik ittifakın kurulmas1nın ardından düşünebileceklerini belirtmektedirler. Dolayısıyla çevrimiçi yürütülen psikoterapiler, yüz yüze terapilerin bir muadili değil, belirli koşulların sağlanmasının ardından ya da yüz yüze terapinin mümkün olmamasının kesinleşmesi durumlarında kullanılabilecek bir bağlam olarak değerlendirilmektedir.

Katılımeı 26: 'Danışana ulaşmanın fiziksel olarak zorlayıcı olduğu durumlarda psikoterapi hizmetinin verilememesi gibi bir sonuç yerine tercih edilebilir bir yol ve alternatif olduğunu düşünüyorum'

Katılımı 32: '...Şimdi bu durumda online olarak sandalye tekniğini uygulamak oldukça zor geldi. Aynı durum oyun terapisinin her aşaması için de geçerli. Ancak her ne kadar danışandan danışana değişse de belirli bir süre görüşme yapıldıktan sonra-yaklaşık 1 yll ya da 8-9 ay olabilir-bir ilişki kurulduysa zorunlu koşullardan dolayı online terapilere geçiş yapılabilir gibi geliyor.'

Katılımcı 37: '...Ancak bunun için öncelikle birkaç yüz yüze görüssme yapılmış, sinırların ve sürecin 
belirlenmiş olması kaydıyla uygun olacağını, en azından duruma göre ayda iki ayda bir yüz yüze görüşmelerin tekrarlanmasi gerektiğini düşünüyorum. Yoksa ilk görüşmeden itibaren online olarak görüssme yürütmek belirli terapötik zeminlerin tanımlanmasında ve insan iletişimindeki temel noktaları kurmada sorun yaratacaktır.'

Katılımcı 48: 'Yalnızca zorunlu durumlarda (örneğin taşınma $v b$. sebeplerle sürecin yarlda kesilecek olması veya fiziksel imkanların -ulaşılabilirliğinkisitlı olmasl gibi), deneyimli terapistler tarafindan yapılmasının uygun olduğınu düşünüyorum.'

\section{Tema 4: 'Özel eğitim ve bilgi gerektiren' bir bağlam olarak çevrimiçi psikoterapi}

Çevrimiçi yürütülen psikoterapiler, araştırmada yer alan psikoterapistlere göre belirli bir eğitim ya da bilgi sahibi olunduğu koşullarda kullanılabilir. $\mathrm{Bu}$ noktada katılımcılara göre hem danışanın hem de psikoterapistin teknoloji kullanımına hâkim olması, teknik aksaklıkları yönetebilecek bilgiye sahip olmas1 ve yüz yüze terapilerden farklılaşan sorunlarla nasıl baş edebileceği konusunda yetkin olması gibi gereklilikler söz konusudur. Özetle katılımcılar, çevrimiçi yürütülen psikoterapilerin yüz yüze yürütülen geleneksel psikoterapi bağlamına göre daha farklı bir yetkinlik ve yeterlik gerektirdiğini bildirmektedirler.

Katılımcı 33: 'Danışanın bilgisayar kullanımı gibi teknolojiyle ilgili konularda yeterli bilgisinin ve pratiğinin olmaması; özellikle yaşlılarda kullanım zorlaşabilir.'

Katılımcı 16: 'Bu konuda özel bir eğitim alan psikoterapistlerce uygulanmasının gerekliliğini savunuyorum. Bu yolla yapllacak bir görüssmeden önce terapinin nastl yürütüleceğine ve gizliliğin ne durumlarda bozulabileceğine dair karşılıklı onam alınmasının önemli olduğunu düşünüyorum.'

Katılımcı 33: '...Ayrıca danışana zarar vermemek ve fayda sağlamak açısından terapistlerin online terapi anlaminda yetkin ve yeterli olmasi gerekir.'

Katılımcl 19: 'Terapistin internet üzerinden terapi yapma konusunda bilgi ve donanimlı olmast, olast sinırlılıkların farkında olması ve bunları gözetebilmesi önemli.'

\section{Tema 5: 'Suistimale açık' bir bağlam olarak çevrimiçi psikoterapi}

Psikoterapistlerden elde edilen verilere göre, belirlenen bir diğer tema çevrimiçi yürütülen psikoterapilerin hem danışanlar, hem terapistler, hem de psikoterapist olabilmek için gerekli eğitime sahip olmayan kişiler tarafindan suistimal edilebilecek bir bağlam olarak görülmesidir. Katılımcılara göre danışanlar yüz yüze terapilere kıyasla psikoterapötik çerçeveyi bozacak davranışları (seansların gö- rüntü kaydının alınması, görüşmelerin yapıldığı odada bir başkasının da bulunması, görüşmenin gerçekleştirildiği ortama aniden birinin girebilmesi gibi) daha kolay gerçekleştirebilirler; psikoterapistler daha fazla danışan takip edebilmek için uygun olmayabilecek reklam ve tanıtım gibi yollara yönelebilirler; psikoterapist olmak için yetkinliği olmayan kişilerin denetlenmesi daha zor olacağ uygun olmayan şekilde psikoterapi hizmeti vermeye çalışabilirler. Dolayısıyla psikoterapistlere göre çevrimiçi psikoterapi bağlamları, yüz yüze yürütülen psikoterapilere kıyasla daha çok suistimal edilebilir uygulamalara yol açabilmektedir:

Katılımcı 33: '...Hâlihazırda sahte psikologların olduğu şu dönemde online terapilerin sahte psikologlar arasında yayılması söz konusu olabilir.'

Katılımcı 37: '...Evde online olarak psikoloğunuz bir tık yanınızda gibi uygulamaların tartışılabilir bir noktası bile olmadı̆̆ını söyleyebiliriz.'

Katılımcı 17: 'Psikoterapi sürecinin danışanlara sunduğu çerçevenin çizilemeyeceğini düşünüyorum. Suistimale açık bir konu olduğunu düşünmekteyim.'

Katılımcı 44: 'Gizlilik açısından ve iletiş̧im açısından uygun bulmuyorum. Istismara daha açık hale geliriz. Şarlatan terapistlere daha fazla ortam hazırlar, yasamı bile yokken.'

\section{Tema 6: 'Aksiliklere açık' bir bağlam olarak çevrimiçi psikoterapi}

Araştırmanın bir diğer önemli bulgusu, çevrimiçi psikoterapi bağlamlarının teknik aksaklıklara (internet kesilmesi, donması ya da yavaşlamas1; bilgisayarın ya da mobil cihazların bozulmasi; elektrik kesintileri gibi) yol açabilecek, veri kaybını kolaylaştırabilecek, seslerin iletiminde bazı sorunlar yaratabilecek olması gibi durumları psikoterapistlerin önüne getirebilmesi sebebiyle, yüz yüze geleneksel görüşmelere nazaran daha fazla 'aksiliklere açik' bir bağlam olarak görüldüğüdür. $\mathrm{Bu}$ aksilikler ise katılımc1 psikoterapistlere göre psikoterapilerin temel yapıları olan terapötik ittifakın ve psikoterapötik çerçevenin zarar görmesine neden olabilir:

Katılımcı 14: '...Elime takulınca kapanabilecek bir ekran bendeki bağlanma devrelerini aktive etmezdi diye düşünüyorum.'

Katılımcı 41: '...Internet koptu gibi çerçeve ihlallerinin daha fazla olduğunu gözlemledim.'

Katılımc1 2: 'Teknik sıkıntılar çerçeveyi çok bozuyor, paranın iletilmesi ile ilgili aksaklıklar da olabilir.'

\section{Tema 7: 'Ulaşılabilirliği yüksek' bir bağlam olarak çevrimiçi psikoterapi}

Araştırma verilerine göre, önceki 6 temanın aksine çevrimiçi yürütülen psikoterapilerin olumlu 
görülebilecek özelliklerine atıf yapan bir diğer tema, ulaşılabilirliğinin yüksek olması ve bu açıdan kolaylıklar sağlamasıdır. Katılımcılara göre çevrimiçi yürütülen psikoterapiler farklı şehirlerdeki ve ülkelerdeki danışan-terapist ikilisini bir araya getirebilmekte, psikoterapi hizmetinin zorlukla sağlandı ̆̆ küçük şehirlerde yaşayan danışanlara hizmet sağlama olanağı tanımakta, çalışma saatleri de göreceli olarak esneyebilmekte, acil ve kriz durumlarında hızlı ulaşım sağlamakta, taşınma, uzun süreli seyahat gibi koşullarda sürecin kesintiye uğramas1nın önüne geçilmesinin yolunu açmakta, belirli hastalıkların ya da fiziksel engelliliğin yaratabileceği evden çıkamama durumlarında psikolojik desteğin ulaştırılabilmesinde yardımcı olmaktadır. Kısacası çevrimiçi olarak gerçekleştirilen psikoterapi seanslar1 ve süreçleri zaman ve mekân kısıtlı1ıkları söz konusu olduğunda çeşitlilik sunmaktadır:

Katılımcı 26: 'Fiziki şartların uygunsuzluğu benim için en önemli kriter. Ulaşım imkanı olmayan (yurtdışl, uzak şehir gibi) ve birlikte terapi yürütmeye istekli olan, ihtiyacını bildiğim birini keyifle online terapide takip edebilirim.'

Katılımc1 30: 'Büyükşehirlerin dişında psikoterapist bulmak zor olabiliyor. Yurtdışında yaşamak Türk psikoterapist bulmayl zorlaştırabiliyor. Yatılı ve kronik hastalar ofislere/hastanelere gidemeyebiliyor. Psikoterapist ve hasta bulunduğu yerden ayr-labiliyor ya da hayatlarında değişiklikler olabiliyor. Bitmiş terapilerde hasta terapistle bir kez daha görüşmek isteyebiliyor ancak yüz yüze görüşmek mümkün olmayabiliyor.'

Katılımcı 14: 'Acil durumlarda erişim, psikoloğun olmadiğl yerlerdeki kişilerin hizmete ulaşabilmesi, fiziksel rahatsızlığı olan, evden çıkamayan hastaların ulaşma imkânının olması gibi avantajları söz konusu.'

Tema 8: Yüz yüze terapiden farklı olmayan bir bağlam olarak çevrimiçi psikoterapi

Katılımcıların verdikleri yanttlara göre edinilen sonuçlardan elde edilen son tema ise, çevrimiçi psikoterapilerin yüz yüze terapilerden farklı olmadığıdır. Tıpkı geleneksel yüz yüze psikoterapi bağlamı gibi, çevrimiçi psikoterapiler de ruh sağlı̆̆ına yapılan psikoterapötik müdahalelerin önemli ve kullanılabilir bir alternatifidir:

Katılımcı 18: 'Çerçevenin iyi belirlendiği ve oturtulduğu durumlarda, etkinliğinin yüz yüze terapilerden farklı olmadığına inanıyorum. Ayn zamanda, uzmanlara erişimi kısitlı olan kişilerin (ör: küçük şehirlerde yaşayan ya da herhangi bir fiziksel rahatsızlı nedeniyle evden çıkmakta zorlanan) oldukça faydalanabileceği bir hizmet olarak görüyorum.'
Katılımcı 28: 'Psikoterapi tekniklerinin online olarak uygulanması online olmayan terapilerdeki kadar mümkün.'

Katılımcı 2: 'Online terapilerde terapötik ilişkinin olumsuz etkileneceğini düşünmüyorum, insan insana ilişki aynı samimiyetle online terapilerde de yürütülebilir.

Katılımcı 26: 'Danışana göre değişebilir diye düşünüyorum, tıpkı yüz yüze terapide olduğu gibi. Kendi adıma ittifakımızın iyi kurulduğunu düşündügüm danışanlarım var, şu ana kadar sorun hissetmedim. Ah keşke yüz yüze olsaydı bu süreç, demedim.'

\section{Çevrimiçi terapi bağlamın deneyimleyen ve deneyimlememiş olan psikoterapistler arasındaki farklar}

Çalışmadan elde edilen bir diğer önemli bulgu ise çevrimiçi psikoterapi deneyimi olan psikoterapistler ile deneyimi olmayan psikoterapistlerin ifadelerindeki farklılaşmadır. Daha önce çevrimiçi psikoterapi bağlamını kullanmış olan terapistlerin daha deneyime dayalı, somut ve net ifadeler kullandıkları, daha önce kullanmamış olan psikoterapistlerin ise daha varsayımsal ve olasılıklı ifadelere başvurdukları gözlenmiştir:

Katılımeı 22: 'Yaşantısal teknikleri uygulamada klsitlllıklar söz konusu olabiliyor.'

Katılımcı 43: 'Şu ana kadar mecburiyetler nedeniyle var olan süreçlerimin devam seanslarını skype üstünden yürüttüm. Danışanımla yüz yüze bağ kurmuş olduğum için ilk başta tuhafima gitse de bir süre sonra kendimi rahat hissettim.'

Katılımcı 46: 'Psikanalitik çalışıyorum, bu sebeple yüz yüze seans çerçevesini online'a uyguladım. Ben arada terapötik ilişki kurulduktan sonra eğer psikotik özellikler veya intihar riski gibi kriz durumlar yoksa ve danışan belli bir mesafeyi tolere edebilecekse online seans yapıyorum. Bu sürede de belli slkliklarla yüz yüze seans da ekliyorum.'

Katılımcı 32: 'BDT teknikleri uygulanabilir belki ama yaşantısal teknikler uygulanamaz gibi geliyor.' Katılımcı 17: 'Terapötik ittifak kurulması konusunda oldukça şüpheliyim.'

Katılımcı 30: 'Bence önce yüz yüze görüşme yapıp internete geçilmesi ittifak açısından daha iyi olabilir. Ancak başından beri internetle devam eden görüşmeler de olabilir. Bu iki ittifak arasında anlamlı bir fark olacă̆ını düşünmüyorum. Belki ittifak kurulma süresinde farklılıklar yaşanabilir.'

\section{Psikoterapistlerin çevrimiçi psikoterapilere ilişkin eylemsel öngörüleri \\ $\mathrm{Bu}$ araştırmada yer alan psikoterapist katılımcılara, çevrimiçi psikoterapilere yönelik algılarını anlaya- bilmek amaciyla yöneltilen ve kodlanan 6 temel}


sorunun yanı sıra; farklı iki varsayımsal koşulu içeren soru ile eylemsel öngörüleri de anlaşılmaya çalışılmıştır. Bu amaç doğrultusunda katılımcılara yöneltilen sorular şu şekildedir: 1) Yetkinlik alanınıza girmeyen ve size başvuran bir danışanınızı bu konuda internet üzerinden yürütülen terapi yaptığını bildiğiniz bir meslektaşınıza yönlendirir misiniz? 2) İnternet üzerinden psikoterapi süreci yürütülen bir terapiye, kendiniz danışan olarak gitmeyi tercih eder miydiniz? Katılımcıların vermiş oldukları yanıtlar 3 ana başlık altında kodlanmıştır: 1) Evet, 2) Hayır ve 3) Koşullu evet (ilk tercihi olan yüz yüze terapinin mümkün olamadığı koşullar vb.). Elde edilen bulgular Tablo 3'te sunulmuştur. Elde edilen bulguların psikoterapistlerin çevrimiçi algılarına yönelik elde edilen temalarla tutarlılık gösterdiği görülmektedir. Psikoterapistlerin büyük bir kısmı (\%65'i) kendilerine başvuran danışanları ya çevrimiçi bir psikoterapi yapan meslektaşlarına yönlendirme yapmamayı tercih etmekte ya da yönlendirme konusunda önceliği yüz yüze psikoterapi yapan meslektaşlarına vermekte, çevrimiçi terapiyi 'yedek' ya da 'zorunlu kalınırsa düşünülebilecek' bir bağlam olarak görmektedir. Elde edilen bulguların en çarpıcı kısımlarından biri ise, katılımcı psikoterapistlerin \%85.5'inin çevrimiçi yürütülen bir psikoterapiye gitmeyeceklerini ya da önceliklerinin yüz yüze yürütülen bir psikoterapi olduğunu bildirmeleridir.

Tablo 3. Psikoterapistlerin Çevrimiçi Psikoterapilere İlişkin Eylemsel Öngörüleri

\begin{tabular}{lccc}
\hline & Evet & Hayır & $\begin{array}{l}\text { Koşullu } \\
\text { Evet }\end{array}$ \\
\hline $\begin{array}{l}\text { Çevrimiçi } \\
\text { psikoterapi }\end{array}$ & $\% 35$ & $\% 27$ & $\% 38$ \\
$\begin{array}{l}\text { yapan bir } \\
\text { meslektaşa } \\
\text { yönlendirme }\end{array}$ & & & \\
\hline $\begin{array}{l}\text { Çevrimiçi } \\
\text { psikoterapiye } \\
\text { gitmeyi } \\
\text { tercih etme }\end{array}$ & $\% 12,5$ & $\% 52$ & $\% 33,5$ \\
\hline
\end{tabular}

\section{TARTIŞMA}

$\mathrm{Bu}$ çalışmanın amacı, psikoterapistlerin teknolojinin ve internetin kullanım alanlarının giderek gelişmesi ile birlikte yaygınlaşan çevrimiçi olarak yürütülen psikoterapi süreçlerine ilişkin algılarının nitel bir yöntem olan tematik analiz ile incelenmesidir. Türkiye alanyazınında daha önce böyle bir çalışmanın yapıldığına dair bir bulgu bu çalışmanın araştırmacıları tarafından elde edilememiştir; dolayısıyla özgün bir araştırma olduğu söylenebilir. Mora ve arkadaşlarının (2008) vurguladığı üzere psikoterapistlerin psikoterapi uygulamalarını çevrimiçi bağlamda yürütme konusundaki düşünceleri ve algıları, söz konusu alanyazının gelişimine, araştırmaların ve uygulamaların içeriğinin ve odak noktasına taş1dıkları değişkenlerin etkilenmesine yol açabilmesi sebebiyle oldukça önemlidir. Bu anlamda araştırma sorusu, nitel yöntemlerin sağlayacağ 1 derinlikli analiz imkânı doğrultusunda araştırmacılar tarafından şekillendirilmiştir.

Elde edilen bulgulara göre, ülkemizdeki psikoterapistler dünyadaki diğer psikoterapistlerle paralel kaygılar yaşamaktadırlar. Veriler incelendiğinde ilk ve en dikkat çekici temanın çevrimiçi psikoterapilerin kayg1 uyandıran bir bağlam olarak görülmesi; özellikle psikoterapötik çerçeve, psikoterapötik ittifak ve etik gibi temel konuların tartışıldığı alanyazınla tutarlılık göstermektedir (Wangberg ve ark., 2007; Young, 2005). Özellikle bu kaygılar, tüm sürecin çevrimiçi olarak yürütüldüğü durumlarda artmaktadır. Bu noktada göz önünde bulundurulmas1 gereken değişken, psikoterapistlerin çevrimiçi ortamda psikoterapi yürütme deneyiminin varlığ 1 olabilir. Kat1lımc1 psikoterapistlerin \%66.7'sinin daha önce psikoterapi uygulamalarında çevrimiçi bağlamı kullanmadığ düşünüldüğünde, belirsizlik söz konusu kavramlar açısından önemli düzeyde kaygı uyandırıyor olabilir. Çünkü daha önceden çevrimiçi süreci deneyimlemiş psikoterapistler açıklamalarında deneyimlerini aktarabilmekte, söylemlerinde varsayımsal ifadeler yerine daha somut ve deneyime dayalı açıklamalar kullanabilmektedirler. Dolayısıyla ülkemiz psikoterapi araştırmalarının dünya alanyazınıyla senkronize ilerleyebilmesi açısından, bu kaygıların ele alındığı ve giderilme yollarının çalışıldığ 1 araştırmaların yürütülmesi ve bulgularının tartışılması önem taşımaktadır.

Katılımc1 psikoterapistlerden elde edilen veriler, çevrimiçi psikoterapi bağlamının 'uygun olmadığı' yönünde bir temaya ulaşmamızı sağlamıştır. Buna göre psikoterapi doğası gereği terapist(ler) ve dan1şan(lar)ın aynı anda, aynı odada bulunduğu ortamlar dışında uygulanmaya elverişli değildir. Katılımc1ların sanal bir ortam üzerinden psikoterapi uygulamalarına görece daha 'katı şekilde' baktıkları söylenebilir. Özellikle sözel olmayan verilerin çevrimiçi müdahaleler sırasında kaçırılabileceğini vurgulayan psikoterapistler, bu kaybın başta terapötik ilişkinin kurulumuna engel olacağını varsayarak; bu konuyla ilgili diğer temadaki gibi kaygı, endişe ya da şüphe sunmaktan ziyade doğrudan uygun olmadığı ifade etmektedirler. Özetle, psikoterapide yüz yüze olmak, olmazsa olmaz bir koşuldur.

Çevrimiçi psikoterapilerin ancak yüz yüze terapilerin yürütülmesinin mümkün olmaması ve yüz yüze seansların da mutlaka sürece dâhil edilmesi gibi koşullara bağlı olarak gerçekleştirilebileceğinin ifade edilmesi, bu yeni sanal bağlamın yüz yüze terapilerin bir muadili/alternatifi değil 'yedeği' gibi görüldüğü temasına ve sonucuna ulaşmamızı 
sağlamaktadır. Oysa teknolojik gelişmelerin sunduğu imkanlar, çevrimiçi psikoterapilerin yanı sıra eposta aracılığıyla terapi, bilgisayar temelli psikoterapi gibi pek çok farklı uygulamayı da beraberinde getirmektedir (Wangberg ve ark., 2007). Çevrimiçi psikoterapiler, senkronize olmayan bu uygulamalara kıyasla daha çok etkileşim olanağı sunmakta, terapist ve danışanın eş zamanlı varlığını sağlayabilmektedir. Yine de Türkiye'deki bu çalışmaya katılan psikoterapistler için çevrimiçi yürütülen psikoterapilerin sağladığı bu olanakların yeterli ve kapsayıcı görülmediği, 'yedek' ve kullanımı koşullara bağlı düzeyde kaldığı söylenebilir.

Kullanılan psikoterapötik yaklaşım ve teknikler farklılaşmasa da, çevrimiçi yürütülen psikoterapilerin özel bir eğitimi ve bilgi edinimi gerekliliğini de beraberinde getirdiğinin düşünülmesi, çalışmamızda elde edilen önemli bir diğer bulgudur. Psikoterapistler bu noktada karşılaşabilecekleri zorlu durumlarla baş edebilme yollarını öğrenmenin, teknoloji kullanımı ve sorun çözme konusundaki hâkimiyetin önemli olduğunu belirtmektedirler. Dolayısıyla çevrimiçi psikoterapilerin, yüz yüze geleneksel psikoterapi uygulamalarından farklılaşan bir yetkinliğe sahip olmayı gerektiği görüşü alan yazında farklı çalışmalarda ortaya atılmış (Griffiths ve Cooper, 2003; Orr, 2012); bu çalışmada da desteklenmiştir.

Çalışmamızda çevrimiçi psikoterapilere yönelik algılardan bir diğeri de, bu bağlamın yüz yüze terapiden daha fazla suistimal edilebilir bir pratik olduğu yönündedir. Bu suistimal psikoterapistlere göre pek çok açıdan gerçekleşebilir. Örneğin yüz yüze terapilerde görüşme odasının tüm kontrolü görüşmeyi yürütecek uzmanın elindedir. Görüşmeye kimlerin dâhil edileceği ya da edilmeyeceği, ses yalıtımının sağlanması, görüşmelerin kayıtlarının alınıp alınmayacağı gibi konularda psikoterapistler, yüz yüze görüşmelerde kendilerini daha güvende hissetmekte; danışan tarafından suistimal edilme olasılığ 1 ise çevrimiçi terapilerde artmaktadır. Ya da psikoterapi uygulamaları yapabilmek için gerekli eğitimi almamış ve yetkinliği olmayan kişilerin, çevrimiçi bağlamlarda 'psikoterapistlik' mesleğini daha kolaylıkla kötüye kullanabileceklerini ve bu konudaki denetimin daha sınırlı kalabileceğini düşünmektedirler. Griffiths ve Cooper (2003) tarafindan çevrimiçi terapilerin avantaj ve dezavantajlı alanlarını tespit etmek amaçlı yürütülen çalışmada da bu bulguları destekler niteliktedir.

Diğer yandan, çevrimiçi psikoterapiler, seans esnasında karşılaşılabilecek aksiliklere ve sorunlara daha açı durumdadır. Bunun nedeni, hepimizin günlük hayatımızda karşılaşabileceğimiz internetin kesilmesi, yavaşlaması, donması, elektiriğin kesilmesi, kullanılan aracin (bilgisayar, mobil cihaz gibi) bozulması ya da kapanması gibi sorunların çevrimiçi seansları olumsuz şekillerde etkileyebileceğidir (Castelnuova ve ark., 2003; Cook ve Doyle, 2002). Bu sorunlardan farklı ancak görüşmeyi ketleyebilecek pek çok sorun yüz yüze terapilerde de söz konusu olabilse de çalışmaızmdaki katılımcı psikoterapistler, çevrimiçi psikoterapiler söz konusu olduğunda bu 'aksilikler'e daha fazla vurgu yapmaktadırlar.

Özetlenen temalar ve elde edilen bulgular bu çalışmanın katılımcıları özelinde, çevrimiçi psikoterapilerin olumsuz özelliklerine işaret etmektedir. Temaların daha çok bu eksende olması, Türkiye'de çalışan psikoterapistlerin algılarının yönü hakkında bizlere önemli bilgiler sunmaktadır. Ancak verilerden elde edilen diğer iki tema, çevrimiçi psikoterapilerin olumlu sayılabilecek özelliklerine atıfta bulunmaktadır. $\mathrm{Bu}$ temalardan ilki, alanyazındaki görüşlerle tutarlı olarak çevrimiçi psikoterapilerin ulaşılabilirliğinin kolaylığıdır. Çevrimiçi terapiler, psikoterapistler tarafından özellikle şehir değişikli$\breve{g i}$, uzun süreli seyahatler, fiziksel engellilik veya hastalık sebebiyle görüşmenin yapılacağı ofise ulaşamama gibi sebeplerle başlatılamayan, kesintiye uğrayan ya da sonlandırılan süreçler için kullanılabilecek bir yol olarak görülebilmektedir. Dolayısıyla, çevrimiçi psikoterapilere bir yanıyla hâlen şüpheyle yaklaşıldığı söylenebilse de, diğer yanıyla önemli bir ihtiyacı karşıllyor ve eksikliği tamaml1yor şeklinde algılandığı söylenebilir. Son olarak; psikoterapistlerin çevrimiçi psikoterapilere yönelik algilarından biri de yüz yüze terapiden herhangi bir farkı olmadığı yönündedir. Buna göre uygulanan teknikler, kullanılan yaklaşım, uygulayacak psikoterapist yüz yüze terapi ile aynıdır ve belirli düzenlemeler çevrimiçi psikoterapiler tıpkı yüz yüze psikoterapi bağlamında olduğu şekliyle gerçekleştirilebilir.

Türkiye'de çalışan psikoterapistlerin psikoterapilerin çevrimiçi ortamda yürütülmesine ilişkin algılarının ve düşüncelerinin incelenmesinin hedeflendiği bu çalışmadan elde edilen bulgular, katılımc1 psikoterapistlerin bu bağlamın kolaylaştırıcı etkilerinin farkında olmalarına rağmen, hâlen olumsuz özelliklerine ve zorlayıcı durumlara ilişkin yaşayabilecekleri kaygılara atıfta bulunduklarını göstermektedir. Bu durum çalışma örnekleminin büyük kısmının (örneklemin yaklaşık \%66.7'si) daha önce çevrimiçi psikoterapi sürecini hiç deneyimlememiş olmasından kaynaklanıyor olabilir. Psikoterapistlerin bu algılarının farkında olabilmek, ülkemizde de giderek kullanımı artan çevrimiçi bağlamın nasıl geliştirilebileceğine, hangi önemli konuların göz önünde bulundurulması gerektiğine, bulgulanan temalar doğrultusunda söz konusu alanın nasıl şekillenebileceğine ilişkin önemli noktalara değinebilmemizi sağlayacaktır. Çevrimiçi psikoterapi bağlamı, her ne kadar aktarılan temalar altında 
belirli algıların tartışılmaya açık noktalarını barındırıyor olsa da, tüm dünyada sıklıkla kullanılan, belirli bir alanyazına sahip, gelişime ve ilerlemeye açık ve psikoterapi uygulamalarını kolaylaştırıcı özelliklere de sahiptir. Bu sebeple bu çalışma ile temel adımı atılmıș olan söz konusu alanın daha derinlemesine çalışılmasına ve belirlenen algılar ile kayg1ların araştırmacılar tarafından ileriki çalışmalarda incelenerek ülkemiz alanyazınında da ele alınmasına ihtiyaç duyulmaktadır. Çalışmanın güçlü yanlarından biri, doğrudan psikoterapistlere ulaşılarak tamamen gizlilik esasına dayalı şekilde araştırma sorusuna ilişkin düşüncelerini psikoterapistlerin aktarabilmelerine olanak sağlamış olmamızdır. Alanda bu algılar için herhangi bir ölçüm aracı kullanılmıyor olsa da, nitel araştırma ve analiz yöntemini kullanmış olmamız daha derinlemesine incelemeler yapabilmemize olanak sağlamıştır. Temaların katılımcilar arasında tekrarlıyor olması, örneklemimizin büyüklüğünün yeterli olduğuna işaret etmektedir. Ancak çalışmamızın en önemli sınırlılığ1, katılımcı psikoterapistlerin görüşlerinin yazılı olarak alınmasıdır. Her bir psikoterapist ile yarı yapılandırılmış formatta gerçekleştirilecek görüşmeler, daha kapsamlı bulgular edinmemizi sağlayabilir. Ayrıca ileriki çalışmalarda, farklı psikoterapi yaklaşımlarını kullanan psikoterapistlerin çevrimiçi terapilere yönelik algılarının ne yönde olduğunun detaylı incelenmesi de alanyazına ve psikoterapi uygulamalarına önemli katkılar sağlayacaktır. Ancak yine de bu çalışma ile ülkemizde çevrimiçi psikoterapiler konusunda psikoterapistlerin alg1lar1nın ve düşüncelerinin incelenerek, bu alandaki çalışmaların kısıtlılığı konusunda araştırmaciların dikkatini çekmek mümkün olabilir.

\section{Sonuç}

Gelişen teknoloji ile birlikte yaşamımızın her alanında etkisini gösteren ve hayatımızı büyük ölçüde kolaylaştırarak vazgeçilmez hale gelen internetin, psikoterapi süreçlerinin de önemli bir parçası olması durumu giderek yaygınlaşmaktadır. Bu süreçte psikoterapistlerin algılarının ve görüşlerinin ele alınması; etkili ve sağlıklı süreçlerin yürütülebilmesi ve bu alanın olumlu yönde geliştirilebilmesi ad1na oldukça önemlidir. Çalışmamız sonucunda elde edilen 8 temanın 6's1 (kayg1 uyandıran bir bağlam olarak çevrimiçi psikoterapi, uygun olmayan bir bağlam olarak çevrimiçi psikoterapi, yedek/koşullu bir bağlam olarak çevrimiçi psikoterapi, özel eğitim ve bilgi gerektiren bir bağlam olarak çevrimiçi psikoterapi, suistimale açık bir bağlam olarak çevrimiçi psikoterapi, aksiliklere açık bir bağlam olarak çevrimiçi psikoterapi) özellikle psikoterapötik çerçeve, psikoterapötik ittifak ve etik gibi temel konuların çevrimiçi psikoterapilerde uygulanabilmesine ilişkin olumsuz yöndeki algılara işaret etmektedir. Ancak bu sonuçların yanı sıra, çevrimiçi psikoterapi bağlamına yönelik olumlu (ulaşılabilirliği yüksek bir bağlam olarak çevrimiçi psikoterapi ve yüz yüze terapiden farklı olmayan bir bağlam olarak çevrimiçi psikoterapi) olarak değerlendirilebilecek temalara da ulaşılmıştır. Diğer bir önemli bulgu da psikoterapistlerin danışanlarını çevrimiçi psikoterapi bağlamını kullanan bir terapiste yönlendirmekle ya da kendilerinin danışan olarak dâhil olabilecekleri psikoterapi süreçlerinin çevrimiçi bağlamda sürmesiyle ilgili tereddütlerinin ve olumsuz kararlarının varlığıdır. Tüm bu bulgular göz önünde bulundurulduğunda, ülkemizde çalışan psikoterapistlerin teknolojinin ve internetin ruh sağlığı alanında kullanımına ilişkin kaygılarının ve olumsuz yöndeki algılarının, katılımcıların büyük çoğunluğu tarafından çevrimiçi psikoterpi sürecinin deyimlenmemiş olmasından kaynaklanıyor olabileceği düşünülmektedir. Yapılan bu çalışmanın, bu alanda yapılacak diğer çalışmalar için rehber olması, ilerleyen çalışmaların ve uygulamaların bu bulguları göz önünde bulundurarak sürdürülmesinin önemine dikkatleri çekmektedir.

\section{Öneriler}

Çalışmamız soncunda terapistlerin çevrimiçi terapiler konusunda esnek olmaya yatkın oldukları ancak bunun bazı koşullara dayandırdıkları görülmektedir. Bunların en başında psikoterapötik çerçevenin kurulması ve teknik-donanımsal bilgi eksikliklere yaptıkları vurgu gelmektedir. Bu süreçte donanımsal alt yapının güçlendirilmesi, danışan - terapist gizliliğinin korunması için kurumsal alt yapıya sahip yazılım programlarının kullanılmasının oldukça yarar sağlayacağı düşünülmektedir. Bunun yanı sıra çevrimiçi psikoterapilerde koşul ve şartların gözden geçirilmesi, Türk Psikologlar Derneği Etik Süreç Yönetmeliği'nin yeniden düzenlenmesi düşünülebilir. $\mathrm{Bu}$ yolla çevrimiçi süreçlerin hem psikoterapist hem de danışan açısından güvenilirliğinin yasa ve kanun önünde de güvence altına alınmasının bu alana ilişkin algılarda değişiklik yaratabileceği düşünülmektedir. Ayrıca çevrimiçi psikoterapi süreçlerinin süpervizyonlar ile desteklenmesi, deneyimsiz psikoterapistlerin aşinalığını arttıracağı ve alg1larının olumlu yönde değişebileceği düşünülerek önerilmektedir. Üniversitelerin ilgili alanlarında lisans ve/veya lisansüstü düzeyinde psikoterapist eğitimlerinde çevrimiçi psikoterapi yöntemlerinin, geleneksel yöntemden farklı olarak dikkat edilmesi gereken özelliklerinin vurgulandığı ilgili dersler/konular bulunmasının yararlı olabileceği düşünülmektedir. Son olarak, ülkemiz alanyazınında internet ve teknoloji temelli psikoterapi uygulamalarının ve psikolojik müdahalelerin araştırma 
konusu olarak çalışılmasının yaygınlığının artması, dünya alanyazını ile paralel gelişmeleri sağlayabilmemiz açısından da oldukça önem taşımaktadır.

\section{KAYNAKLAR}

Almlöv, J., Carlbring, P., Berger, T., Cuijpers, P. ve Andersson, G. (2009). Therapist factors in internetdelivered cognitive behavioral therapy for major depressive disorder. Cognitive Behaviour Therapy, 38(4), 247-254.

Andersson, G. (2009). Using the internet to provide cognitive behaviour therapy. Behavior Research and Therapy, 47, 175-180.

Andersson, G., Cuijpers, P., Carlbring, P., Riper, H. ve Hedman, E. (2014). Guided internet-based vs. faceto-face cognitive behavior therapy for psychiatric and somatic disorders: A systematic review and metaanalysis. World Psychiatry, 13(3), 288-295.

Andersson, G., Paxling, B., Wiwe, M., Vernmark, K., Felix, C. B., Lundborg, L., ...Carlbring, P. (2012). Therapeutic alliance in guided internet-delivered cognitive behavioural treatment of depression, generalized anxiety disorder and social anxiety disorder. Behaviour Research and Therapy, 50, 544-550.

Antony K. (2000). Counselling in cyberspace. Counselling Journal, 11(10), 625-627.

Barak, A., Klein, B. ve Proudfoot, J. G. (2009). Defining internet-supported therapeutic interventions. Annals of Behavioral Medicine, 38(1), 4-17.

Beattie, A., Shaw, A., Kaur, S. ve Kessler, D. (2009). Primary-care patients' expectations and experiences of online cognitive behavioural therapy for depression: A qualitative study. Health Expectations, 12, 45-59.

Bordin, E. S. (1979). The generalizability of the psychoanalytic concept of working alliance. Psychotherapy: Theory, Research and Practice, 16, 252-260.

Braun, V. ve Clarke, V. (2006). Using thematic analysis in psychology. Qualitative Research in Psychology, 3, 77-101.

Castelnuovo, G., Gaggioli, A., Mantovani, F. ve Riva, G. (2003). New and old tools in psychotherapy: The use of technology for the integration of the traditional clinical treatments. Psychotherapy: Theory, Research, Practice, Training, 40(1/2), 1-12.

Cook, J. E. ve Doyle, C. (2002). Working alliance in online therapy as compared to face-to-face therapy: Preliminary results. CyberPsychology \& Behavior, 5(2), 95-105.

Day, S. X. (1999). Psychotherapy using distance technology: A comparison of face-to-face, video, and audio treatments (Yayınlanmamış doktora tezi). Illinois State University, USA.

Day, S. X. ve Schneider, P. L. (2002). Psychotherapy using distance technology: A comparison face-toface, video, and audio treatment. Journal of Counseling Psychology, 49(4), 499-503.

Griffiths, M. ve Cooper, G. (2003). Online therapy: Implications for problem gamblers and clinicians. British Journal of Guidance and Counselling, 31(1), 113135.
Haberstroh, S., Duffey, T., Evans, M., Gee, R. ve Trepal, H. (2007). The experience of online counseling. Journal of Mental Health Counseling, 29(3), 269-282.

Hanley, T. (2004). Online counseling: A heuristic study examining the relational depth of computer-mediated relationships (Yayınlanmamış yüksek lisans tezi). University of Manchester, UK.

Hartwich, P. ve Brandecker, R. (1997). Computer-based art therapy with inpatients: Acute and chronic schizophrenics and borderline cases. The Arts in Psychotherapy, 24(4), 367-373.

Hovarth, A. O., Del Re, A. C., Flückiger, C. ve Symonds, D. (2011). Alliance in individual psychotherapy. Psychotherapy, 48(1), 9-16.

Johansson, R. ve Andersson, G. (2012). Internet-based psychological treatments for depression. Expert Review of Neurotherapeutics, 12(7), 861-870.

Kenardy, J. A., Dow, M. G. T., Johnston, D. W., Newman, M. G., Thompson, A. ve Taylor, C. B. (2003). A comparison of delivery methods of cognitive behavioral therapy for panic disorder: An international multicenter trial. Journal of Consulting and Clinical Psychology, 71(6), 1068-1075.

Kiropoulos, L. A., Klein, B., Austin, D. W., Gilson, K., Pier, C., Mitchell, J. ve Ciechomski, L. (2008). Is internet-based CBT for panic disorder and agoraphobia as effective as face-to-face CBT? Journal of Anxiety Disorder, 22(8), 1273-1284.

Klein, B., Mitcell, J., Abbott, J., Shandley, K., Austin, D., Gilson, K., ...Redman, T. (2010). A therapistassisted cognitive behavior therapy internet intervention for posttraumatic stres disorder: Pre-post and 3month follow-up results from an open trial. Journal of Anxiety Disorders, 24, 635-644.

Knaevelsrud, C. ve Maercker, A. (2006). Does the quality of the working alliance predict treatment outcome in online psychotherapy for traumatized patients? Journal of Medical Internet Research, 8(4):e.31.

Knaevelsrud, C. ve Maercker, A. (2007). Internet-based treatments for PTSD reduces distress and facilitates the development of strong therapeutic alliance: A randomized controlled clinical trial. BMC Psychiatry, 7(1), 13.

Knaevelsrud, C. ve Maercker, A. (2009). Long-term effects of an internet-based treatment for posttraumatic stres. Cognitive Behaviour Therapy, 38, 1-6.

Lange, A., Rietdijk, D., Hudcovicova, M., Van de Ven, J. P., Schrieken, S. ve Emmelkamp, P. M. G. (2003). Interapy: A controlled randomized trial of the standardized treatmant of posttraumatic stress through the internet. Journal of Counsulting and Clinical Psychology, 71(5), 901-909.

McKenna, K. Y. A. (1998). The computers that bind: Relationship formation on the internet (Yayılanmamiş Doktora Tezi). Ohio University, USA.

Mora, L., Nevid, J., ve Chaplin, W. (2008). Psychologist treatment recommendations for Internet-based therapeutic interventions. Computers in Human Behavior, 24(6), 3052-3062.

Norcross, J. C., Hedges, M. ve Prochaska, J. O. (2002). The face of 2010. A Delphi poll on the future of psychotherapy. Professional Psychology: Research and Practice, 33, 316-322. 
Orr, P. (2012). Technology use in art therapy practice: 2004 and 2011 comparison. The Arts in Psychotherapy, 39(4), 234-238.

Preschl, B., Maercker, A. ve Wagner, B. (2011). The working alliance in a randomized controlled trial comparing online with face-to-face cognitivebehavioral therapy for depression. BMC Psychiatry, 11(1), 189

Rees, C. S. ve Stone, S. (2005). Therapeutic aliance in face-to-face versus videoconferenced psychotherapy. Professional Psychology: Research and Practice, 36(6), 649-653.

Reynolds, D. J., Stiles, W. B. ve Grohol, J. M. (2006). An investigation of session impact and alliance in internetbased psychotherapy: Preliminary results. Counseling Psycotherapy Research, 6(3), 164-168.

Rochlen, A. B., Zack, J. S. ve Speyer, C. (2004). Online therapy: Review of relevant definitions, debates, and current empirical support. Journal of Clinical Psychology, 60(3), 269-283.

Spence, S. H., Donovan, C. L., March, S., Gamble, A., Anderson, R., Prosser, S., ...Kenardy, J. (2008). Online CBT in the treatment of child and adolescent anxiety disorders: Issues in the development of BRAVE-ONLINE and two case illustrations. Behavioural and Cognitive Psychotherapy, 36, 411-430.

Stofle, G. S. (2001). Choosing an online therapist. Harrisburg: White Hat Communications.

Suler, J., Barak, A., Chechele, P., Fenickel, M., Hsiung, R., Maguire, J., ...Walker-Schmucker, W. (2001). Assessing a person's suitability for online therapy. CyberPsychology \& Behavior, 4, 675-679.

Taylor, C. B. ve Luce, K. H. (2003): Computer and internet-based psychotherapy interventions. Current Directions in Psychological Science, 12(1), 18-22.

Wagner, B., Brand, J., Schulz, W. ve Knaevelsrud, C. (2012). Online working alliance predicts treatment outcome for posttraumatic stres symptoms in Arab war-traumatized patients. Depression and Anxiety, 29(7), 646-651.

Wagner, B., Horn, A. B. ve Maercker, A. (2014). Interned-based versus face-to-face cognitive-behavioral intervention for depression: A randomized controlled non-inferiority trial. Journal of Affective Disorders, 152-154, 113-121.

Wagner, B., Knaevelsrud, C. ve Maercker, A. (2006). Internet-based cognitive-behavioral therapy for complicated grief: A randomised controlled trial. Death Studies, 30, 429-453.

Wangberg, S. C., Gammon, D. ve Spitznogle, K. (2007). In the eyes of the beholder: Exploring psychologists' attitudes towards and use of e-therapy in Norway. Cyberpsychology \& Behavior, 10, 418-423.

Warmerdam, L., Straten, A., Jongsma, J., Twisk, J. ve Cuijpers, P. (2010). Online cognitive behavioral therapy and problem-solving therapy for depressive symptoms: Exploring mechanism of change. Journal of Behavior Therapy and Experimental Psychiatry, 41, 64-70.

Wolf, A. W. (2011). Internet and video technology in psychotherapy supervision and training. Psychotherapy, 48(2), 179-181.
Yorulmaz, O., Sapmaz-Yurtsever, S., Gökdag, C., Kaçar-Basaran, S., Göcek-Yorulmaz, E., Yalçin, M. ve Görgü-Akçay, N. S. (2018). The future of pychotherapy in Turkey: Predictions for the next 10 years. The Journal of Nervous and Mental Disease, 206(5), 332339.

Young, K. (2005). An empirical examination of client attitudes towards online counseling. CyberPsychology \& Behavior, 8, 172-177. 